\section{Going for 'green technology'}

\section{Tokyo}

HAVING decided that environment-friendly technology will drive the future economic growth of the world, Japanese industry and government are pouring hundreds of millions of dollars into an effort to establish themselves as first in the field.

As with Japan's past successes in a number of industries, such as chip-making and home electronics, the powerful Ministry of International Trade and Industry (MITI) is the prime backer of the research and development of 'green technology', although funds are also coming from a wide spectrum of Japanese industry and academic institutions.

The past couple of years have seen remarkable growth in government support for the development of such products as biodegradable plastics, substitutes for ozonedestroying chlorofluorocarbons (CFCs), technology to absorb and utilize carbon dioxide, and biotechnology to mop up oil spills.

MITI's push actually began quietly in 1987 - before the global environment became a hot political issue - with a move to establish two semi-private marine biotechnology laboratories to develop useful products from the sea (see Nature 333, 4; 1988). The Shimizu and Kamaishi marine laboratories on the Pacific coast of Japan opened last April.

The two laboratories were built at a cost of $¥ 6,000$ million ( $\$ 44$ million) with investments and loans from 36 companies, city banks, local governments, the Japan Development Bank, the Hokkaido Tohoku Development Finance Public Corporation and MITI's New Energy and Industrial Technology Development Organization (NEDO).
NEDO will provide an additional $¥ 15,000$ million in operating costs over nine years, and another $¥ 7,850$ million will be provided over the same period by 24 participating companies, including shipbuilding, chemical, steel, oil-refining, construction, mining, brewing and paint companies.

The laboratories' original purpose was to isolate new pharmaceuticals and natural anti-fouling agents (for incorporation into ship paint) from marine organisms. But with the rising concern over the global environment, the laboratories are now switching attention to isolation of microorganisms that absorb carbon RITE dioxide or eat up oil spills $\mathrm{CO}_{2}$ absorption: (see box, next page).

Coming close on the heels of the two marine laboratories will be MITI's Research Institute of Innovative Technology for the Earth (RITE). The institute, which will open next year in Kansai Science City between Osaka, Kyoto and Nara, is . likely to be the largest pro- *Matched by an equal investment from private sector. Not all of the ject ever funded by MITI. money assigned by MITI necessarily goes to RITE.

Sixty major companies are investing $¥ 5,000$ million (\$37 million) in RITE, including Kansai Electric Power Company, Tokyo Electric Power Company, Tokyo Gas, NEC, Hitachi, Nissan, NKK, Hankyu Railway Corporation, Kobe Steel, Kawasaki Heavy Industries, cement and construction companies, chemical concerns, trading and life insurance companies, trust banks, and even Wacoal Corporation, Japan's leading manu- facturer of women's underwear.

Local governments in the Kansai area will contribute another $¥ 3,000$ million and provide free land for the institute. And NEDO is pouring in about $¥ 5,000$ million a year to support RITE research, which is being carried out at private companies and MITI's national laboratories until the institute opens.

Like the Shimizu and Kamaishi laboratories, RITE will put a lot of effort into developing biological techniques for absorbing carbon dioxide. But the institute will also investigate chemical processes for carbon-dioxide absorption and will develop substitute G BUDGET FOR THE GLOBAL ENVIRONMENT
Substitute CFCs

Biological hydrogen production

Metallic scrap recycling

earch with private secto data bases

Surveys of global

TOTAL for RITE

Thimizu and

CFCs and biodegradable plastics.

Jiro Kondo, president of the Science Council of Japan and director of the RITE laboratory, says he is pleasantly surprised by the "strong support" industry is giving to what will probably be fairly long-term basic research. And he says that the presidents of Kansai and Tokyo electric power companies, two of the largest private electric power companies in the world, and the head

\title{
US-Japan collaboration to develop oil-eating bacteria
}

\section{Tokyo}

THE Japanese are not going it alone in their quest for environment-friendlytechnology. US and Japanese researchers recently announced an unprecedented joint effort to genetically engineer microorganisms that can mop up oil spills and degrade other man-made chemical pollutants.

The five-year \$15-million project, which will be funded equally by the US National Science Foundation (NSF) and the Research and Development Cooperation of Japan (JRDC), is the first major project to come under the umbrella of the 1988 US-Japan Science and Technology Agreement and is indicative of a new cooperative spirit in basic research between the two rival economic giants.

The microbe project will be led by James Tiedje, director of Michigan State University (MSU) Center for Microbial Ecology, and Kieji Yano, professor of biology at Nagaoka University, a leading authority on the molecular biology of genes involved in biodegradation. The research will be carried out by 20 researchers, half of whom (five Americans and five Japanese) will be based at MSU. The other half will work at Nagaoka University of Technology and the Institute of Physical and Chemical Research (RIKEN) in Japan.

The project is the first US-Japanese collaborative effort under a new programme for joint international research introduced by JRDC, an affiliate of Japan's Science and Technology Agency.

Japan's perceived lack of contribution to basic research has been a serious source of friction with the United States that flared up during renegotiation of the US-Japan science and technology agreement in 1988. But the United States has recently been showing a tendency to collaborate in Japan's efforts to promote international basic research. For example, Japan“s Human Frontier
Science Programme will receive some financial support (albeit small) from the National Institutes of Health (NIH) (see Nature 350, 97; 1991). And the new microbe project is also indicative of a new willingness on the part of the United States to contribute to international Japanese projects.

Tiedje says the research is based on the fact that microbes ultimately consume or degrade all natural organic products, from leaves that fall in a stream to garbage in landfills. He and his Japanese collaborators believe that genetic engineering and an understanding of microbial evolution can be used to produce microbes that can degrade oil spills and other man-made pollutants such as PCBs.

The project provides for "equitable sharing of resources and expertise as well as equitable sharing of patents and other results of economic importance", Tiedje says.
D.S. 
of the powerful Kansai Economic Federation are being "very cooperative".

Japan's electric power companies are particularly keen to develop carbon-dioxideabsorbing technology because they account for about 30 per cent of Japan's total carbondioxide emissions. Heavy industry and chemical companies are also hoping to build carbon-dioxide-absorbing plants for their own use and for sale, while trading companies hope to export the plants overseas.

The push to develop environment-friendly technology is not confined to RITE and the marine laboratories. A small but significant effort is under way at the Department of Biotechnology of Tokyo University of Agriculture and Technology led by Tadashi Matsunaga and backed by industry. Researchers there hope to develop a 'biosolar reactor' that will use genetically engineered photosynthetic microorganisms to absorb carbon dioxide and produce useful extracellular products - a project that is closely linked to the work at Shimizu.

Apart from Matsunaga, two other leading academics are spear heading the efforts to develop biological techniques for absorbing carbon dioxide. Shigetoh Miyachi, former director general of the Institute of Applied Microbiology at Tokyo University is executive director for research at the Shimizu and Kamaishi laboratories. And Isao Karube of the Research Center for Advanced Science and Technology (RCAST) at Tokyo University is a leader of RITE's effort.

They all know each other very well, says Matsunaga, and they all sit on committees judging each others proposals, so it is easy for them to coordinate their research to complement rather than compete with each other. One aspect of the collaborations that may seem unusual to Western eyes is the involvement of banks, trading companies and life insurance firms. These firms do not have any say in the research, Miyachi says.

There are, however, several other reasons for such businesses to participate, says Katsuhiko Umehara, senior deputy director of MITI's Agency of Industrial Science and Technology (AIST). Japan's huge trading companies are very diverse and have technology departments that are always on the lookout for the "seeds of new technology and new business". Banks are "very eagerly seeking new customers" and hope to establish business with the new semi-private research organizations. Finally, he says, there is an element of "matsuri no kifu" - a Japanese phrase that translates roughly as a "donation to the village festival", implying that the companies contribute for no reason other than the wellbeing of the community.

It was, of course, just this type of longterm thinking that helped Japanese industry to dominate the rest of the world in selling such things as video cameras and home stereos. The Japanese are hoping to repeat their success in the coming market for technology to keep the world green.

David Swinbanks.

\section{Algae to the rescue}

\section{Koganei \& Shimizu}

TADASHI Matsunaga and Shigetoh Miyachi, two of Japan's leading microbiologists, believe that tiny, genetically engineered photosynthetic microorganisms may help to solve worries about global warming by mopping up carbon dioxide emitted from power stations and industrial plants. And Japanese industry and MITI are prepared to back their ideas.

Matsunaga, who heads the department of biotechnology at Tokyo University of Agriculture and Technology in Koganei in the outskirts of Tokyo has built a

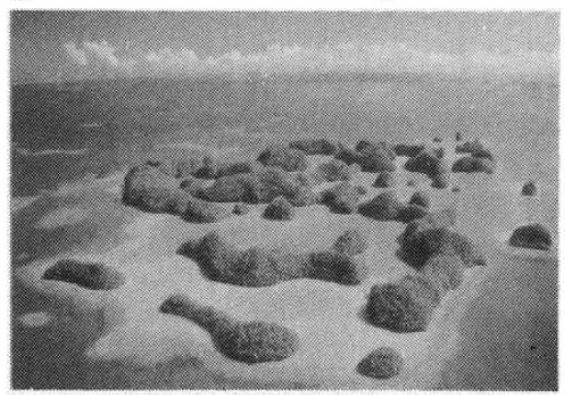

2-litre prototype 'biosolar reactor' that can absorb all the carbon dioxide out of ordinary air bubbled through the reactor at 300 millilitres per minute. The reactor contains a genetically engineered marine cynanobacterium, Synechococcus sp., and is filled with a stack of 600 light-diffusing optical fibre cables that ensure even lighting and optimum growth of the bacterium throughout the vessel.

The optical fibre cables, which, unlike conventional optical fibres, emit light of constant intensity laterally as well as along their length, were developed by a two-man Japanese venture company Science and Technology International and are a vital component of the bioreactor. Previous attempts by Matsunaga's team to absorb significant amounts of carbon dioxide were confounded by the fact that green-coloured photosynthetic microorganisms rapidly attenuate incident light and only those within a few millimetres of the light source can grow efficiently. The stack of closely packed optical fibres overcomes this problem by providing a constant lateral glow. In an industrial-scale biosolar reactor sunlight would be fed into the fibres (hence the name biosolar).

Matsunaga's reactor, however, is still a long way from providing a practical means of absorbing carbon-dioxide emissions from power plants and industry because the levels of carbon dioxide in such emissions are much higher than the 0.03 per cent in air. And high levels of carbon dioxide usually inhibit growth of photosynthetic microorganisms.

But researchers working under Miyachi, who heads MIT's marine biotechnology laboratories in Shimizu and Kamaishi, may have found a solution. They recently isolated a strain of marine green algae off the coast of Kamaishi that grows happily at concentrations of up to 20 per cent carbon dioxide. By isolating the genes responsible for carbon dioxide tolerance, they hope to genetically engineer strains of microorganisms that can efficiently assimilate carbon dioxide at high concentrations.

Even so, it would require an enormous biosolar reactor to cope with the output of a power plant. Matsunaga says a typical megawatt-class power plant emits about 200 tons of carbon dioxide per hour. And if the biosolar reactor absorbed only a few per cent of this it would produce several tons of algal sludge per hour.

Matsunaga and Miyachi differ on how to deal with the sludge. Miyachi hopes to create strains of calcareous algae that can mop up the carbon dioxide and convert it into calcium carbonate that can be dumped at sea. His laboratories have been searching for suitable strains of calcareous algae in coral reefs in Palau and the Great Barrier reef off Australia.

Matsunaga, on the other hand, is trying to create strains of photosynthetic microorganisms that produce useful extracellular products that are released into the green brew of the reactor. For example, the Synechococcus in Matsunaga's prototype reactor has been genetically engineered to produce the amino acid glutamate. And his team have other strains that produce antibiotics and plant growth hormones.

A remarkable feature of the research by the two groups is the enthusiastic backing it is getting from industry. Matsunaga's research is supported by six companies, including a cement manufacturer, Onoda Cement, and Pentel, a maker of ball-point pens, through a new cooperative research centre at Matsunaga's university that was established by the Ministry of Education, Science and Culture last April to encourage collaboration with industry.

The education ministry and industry are providing him with $¥ 30$ million each in fiscal year 1991 to build a 30-litre biosolar reactor and other facilities. And Matsunaga hopes to bring the total up to $¥ 100$ million $(\$ 750,000)$ a year with other donations from industry. He has a team of 30-40 researchers, about a quarter of whom come from the supporting companies.

Similarly, Miyachi's laboratories are staffed almost entirely with people from industry and the laboratories receive substantial support from MITI and private companies. Most of the researchers are beginners in biotechnology and marine science but Miyachi boasts that these 'brave laymen' isolated the strain of marine algae tolerant to carbon dioxide that might one day help solve the global warming problem.

D.S. 